alsflippersada.acid/jurnal/index-pho/TPM

\title{
PENDAMPINGAN PELUANG KEWIRAUSAHAAN PADA MASYARAKAT DUSUN SEKINYAK DALAM BIDANG PARIWISATA
}

Veneranda Rini Hapsari ${ }^{1}$, Usman ${ }^{2}$, Angelus Ewid ${ }^{3}$

${ }^{123}$ Sekolah Tinggi Ilmu Manajemen Shanti Bhuana

Email: rini@shantibhuanal.ac.id,yohanes.usman@shantibhuana.ac.id, ewid@shantibhuana.ac.id

\begin{abstract}
This assistance was carried out in the Sekinyak hamlet, Belimbing Village, Lumar District, Bengkayang Regency, West Kalimantan Province with the aim of helping the community in the hamlet understand the importance of entrepreneurial opportunities amidst the tourism potential in the area. Even though the community already has a livelihood as a farmer, this business opportunity can add income and be a side business. The results achieved in this community service activity are the Sekinyak hamlet community who have an understanding and increase public awareness about entrepreneurship opportunities in the midst of tourism potential in the area, so as to increase income and spur creativity in doing entrepreneurship. The conclusion of the community service activities is that supported by the mentor, the hamlet community will become more understanding about business opportunities in the tourism sector, so that it can become a side job that can increase income.
\end{abstract}

Keywords: assistance, entrepreneurial opportunities, tourism.

\begin{abstract}
Abstrak: Pendampingan ini dilakukan di dusun Sekinyak, Desa Belimbing, Kecamatan Lumar, Kabupaten Bengkayang, Provinsi Kalimantan Barat dengan tujuan untuk membantu masyarakat di dusun tersebut guna memahami pentingnya peluang kewirausahaan di tengah potensi pariwisata di daerah tersebut. Walaupun masyarakat tersebut sudah memiliki mata pencaharian sebagai petani, tetapi dengan adanya peluang usaha ini dapat menambah pendapatan dan sebagai usaha sampingan. Hasil yang telah dicapai dalam kegiatan pengabdian masyarakat ini adalah masyarakat dusun Sekinyak memiliki pemahaman dan meningkatkan kesadaran masyarakat mengenai peluang kewirausahaan di tengah potensi pariwisata di daerah tersebut, sehingga dapat menaikkan pendapatan dan memacu kreativitas dalam melakukan wirausaha. Kesimpulan dari kegiatan pengabdian adalah dengan didukung pendamping, maka masyarakat dusun tersebut, menjadi lebih memahami mengenai peluang usaha di bidang pariwisata, sehingga dapat menjadi pekerjaan sampingan yang dapat menaikkan pendapatan.
\end{abstract}

Kata Kunci: pendampingan, peluang kewirausahaan, pariwisata 


\section{PENDAHULUAN}

Pada sektor usaha di bidang pariwisata merupakan salah satu instrumen yang aktif untuk meningkatkan pendapatan di suatu daerah. Sehingga pengabdian masyarakat ini terfokus pada pendampingan untuk kewirausahaan pada potensi wisata di Dusun Sekinyak, Kecamatan Lumar, Kabupaten Bengkayang, provinsi Kalimantan Barat, terkait rencana adanya pembangunan objek wisata di daerah tersebut, sehingga masyarakat diharapkan dapat mengembangkan pengetahuan yang diperoleh dari pendamping, untuk menambah peluang usaha, sehingga akan menambah pendapatan masyarakat itu sendiri. Untuk itu, pengabdi ingin memberikan suatu kegiatan yang positif, sehingga kelak warga di dusun tersebut mempunyai bekal yang cukup dalam berwirausaha karena potensi pariwisata di daerah tersebut. Rencana dusun Sekinyak dijadikan tempat wisata ini sudah disetujui pemerintah daerah dan sudah dilakukan pembangunan jalan dari dana desa untuk mendukung akses jalan menuju ke tempat wisata tersebut. Menurut kepala desa Belimbing, terdapat objek wisata di dusun Sekinyak, seperti adanya gunung Siang yang masih alami, dibawah gunung terdapat sungai yang jernih, yang akan diberdayakan sebagai objek wisata tempat pemancingan, kemudian adanya gua yang pada zaman itu digunakan sebagai tempat persembunyian oleh G 30 S PKI. Dengan adanya potensi wisata yang telah disebutkan kades tersebut, membutuhkan kerjasama dari berbagai pihak supaya nantinya dapat berkembang dengan baik. Pihak-pihak tersebut seperti pemerintah daerah bersama perangkat desa, pihak akademisi dan yang paling penting adalah dukungan dari pihak masyarakat tersebut. Karena dengan adanya dukungan dari masyarakat maka akan jauh lebih mudah berkembang. Sehingga dengan adanya potensi dan dukungan dari berbagai pihak, maka perlu adanya pihak akademisi sebagai pendamping masyarakat untuk mendorong pola pikir masyarakat dalam berwirausaha guna mengembangkan wisata di desa tersebut. Tetapi, dengan adanya permasalahan saat ini adalah ketika adanya peluang usaha, tetapi tidak dilakukan dan belum dimanfaatkan oleh warga sekitar, sehingga disini pengabdi ingin melakukan pendampingan dalam berwirausaha. Walaupun sebagian besar warga memiliki mata pencaharian sebagai petani, tapi tidak menutup kemungkinan jika para warga tersebut mempunyai usaha sampingan, yang berpotensi ke depannya menjadi mata pencaharian selain bertani. Peran pemerintah daerah dan pihak perguruan tinggi maupun pihak swasta mempunyai peranan penting, karena dengan didukung oleh banyak pihak maka rencana pengembangan pariwisata akan lebih mudah terwujud, sebab dalam pengembangan objek wisata ini perlu adanya dukungan dari berbagai pihak termasuk perhatian dan dukungan dari warga masyarakat sendiri, seperti yang telah dikemukakan sebelumnya.

Jika sejak dari awal sudah ditanamkan untuk berwirausaha dalam benak masyarakat, 
yang mayoritas bermatapencaharian sebagai petani, maka secara tidak langsung akan muncul rasa ingin mencoba suatu usaha, dalam berwirausaha juga secara tidak langsung muncul rasa tanggung jawab, berani mengambil resiko, serta jujur yang akhirnya akan memacu semangat untuk berwirausaha dengan baik. Sehingga kelak jika rencana pembangunan objek wisata berjalan dengan baik, maka masyarakat tersebut sudah siap dengan peluang usaha yang ada. Karena tujuan dari kegiatan pengabdian ini adalah untuk menambah wawasan masyarakat di dusun tersebut mengenai pentingnya berwirausaha, sehingga mampu mewujudkan kewirausahaan yang sesuai dengan harapan. Dalam pendampingan tersebut terdapat sosialiasi yang memamaparkan dasar serta strategi maupun kiat yang dapat memotivasi masyarakat untuk melakukan wirausaha. Tujuan dari pengembangan desa adalah dapat menjadi desa mandiri, yaitu mencerminkan kemauan masyarakat desa yang kuat untuk maju dengan dihasilkan produk/karya.(Puspaningtyas et al., 2018) Kategori desa mandiri juga mengacu pada konsep 3 pilar desa yaitu karsa, karya dan sembada sehingga suatu desa dapat dikatakan desa yang berdikari (Wibowo, 2015)

\section{Analisis Situasi}

Meningkatkan pola pikir masyarakat yang lebih berkembang dalam berwirausaha dan menaikkan taraf hidup dalam masyarakat merupakan salah satu tujuan dari pemerintah untuk membangun. Keberhasilan pengembangan desa wisata tergantung pada tingkat penerimaan dan dukungan masyarakat lokal (Wearing, 2001). Sedangkan menurut Adiyoso (2009) menegaskan bahwa partisipasi masyarakat merupakan komponen terpenting dalam upaya pertumbuhan kemandirian dan proses pemberdayaan.

Menurut Deptan (2004), pendampingan adalah kegiatan dalam pemberdayaan masyarakat dengan menempatkan tenaga pendamping yang berperan sebagai fasilitator, komunikator, dan dinamisator. Tujuan pendampingan agar masyarakat yang didampingi dapat diberdayakan, sesuai tujuan dan sasaran. Menurut Peggy A. Lambing \& Charles R. Kuehl dalam buku Entrepreneur (1999), kewirausahaan adalah suatu usaha yang kreatif yang membangun suatu value dari yang belum ada menjadi ada dan bisa dinikmati oleh orang banyak. Sedangkan tujuan pembangunan pariwisata adalah : 1). Mengembangkan deversifikasi produk dan kualitas pariwisata nasional, 2). Berbasis pada pemberdayaan masyarakat, kesenian dan sumber daya (pesona) alam lokal, 3).mengembangkan serta memperluas pasar wisata (Depbudpar, 2000). Seperti yang telah disebutkan sebelumnya, jika terdapat pariwisata di suatu daerah, maka daerah tersebut akan dapat berkembang, Inskeep (1991) mengatakan bahwa desa wisata merupakan bentuk pariwisata, yang sekelompok kecil wisatawan tinggal di dalam atau di dekat kehidupan tradisional atau di desa-desa terpencil dan mempelajari 
kehidupan desa dan lingkungan setempat. Nuryanti (1992) mendefinisikan desa wisata merupakan suatu bentuk integrasi antara atraksi, akomodasi, dan fasilitas pendukung yang disajikan dalam suatu

struktur kehidupan masyarakat yang menyatu dengan tata cara dan tradisi yang berlaku.

Solusi dalam permasalahan tersebut dapat dilakukan dengan mengadakan:

a. Meningkatkan pengetahuan dan ketrampilan berkaitan dengan jasa boga

b. Meningkatkan kreatifitas mengolah produk

c. Memberikan pengetahuan mengenai pola pikir yang mengarah pada kewirausahaan, sehingga dapat memotivasi masyarakat untuk berwirausaha.

\section{METODE PELAKSANAAN}

Metode penelitian dengan deskriptif kualitatif, dengan rancangan kegiatan berupa pendampingan kepada masyarakat sekitar, ruang lingkup di dusun Sekinyak kecamatan Lumar, sedangkan objek penelitian daerah sekitar yang direncanakan untuk tempat wisata, teknik pengumpulan data dengan primer dan sekunder. Data primer diperoleh dari sumber langsung melalui kepala desa maupun kepala dusun di daerah tersebut, sedangkan untuk data sekunder diperoleh melalui referensi buku. Teknik pengumpulan data yang digunakan adalah observasi, dalam observasi pengabdi dapat mengetahui permasalahan yang bisa digali dari hasil pengamatan tersebut, menurut Arikunto (2006:124) observasi adalah mengumpulkan data atau keterangan yang harus dijalankan dengan melakukan usaha-usaha pengamatan secara langsung ke tempat yang akan diselidiki. Sedangkan untuk wawancara menurut Moleong (2001:112), pencatatan sumber data melalui wawancara atau pengamatan merupakan hasil gabungan dari kegiatan melihat, mendengar, dan bertanya. Wawancara yang dapat dipergunakan untuk mendapatkan informasi lebih lanjut dari nara sumber, seperti yang dikemukakan oleh (Sugiyono,2005:72) "wawancara digunakan sebagai teknik pengumpulan data apabila peniliti ingin mengetahui hal-hal dari informan yang lebih mendalam." Sedangkan menurut Zuriah (2009:179), wawancara ialah alat pengumpul informasi dengan cara mengajukan sejumlah pertanyaan secara lisan untuk dijawab secara lisan pula.Teknik pengumpulan data lainnya berupa dokumentasi

Metode pelaksanaan kegiatan menjelaskan tahapan atau langkah-langkah dan solusi yang ditawarkan untuk mengatasi permasalahan yang memuat hal-hal berikut ini:

1. Pendekatan melalui pendampingan.

Melalui para akademisi, sebagai pengabdi, pendamping dapat melakukan sosialisasi kepada para masyarakat yang disiapkan secara khusus dengan pembekalan teknis dan non-teknis mengenai sistem dan mekanisme cara berwirausaha, sehingga masyarakat dapat 
termotivasi. Hal ini bukan cara yang mudah apalagi bagi masyarakat yang sudah terbiasa dengan keadaan yang lama, dalam arti sudah lama bertani, untuk menjadi wirausahawan memerlukan proses. Tapi jika pendampingan dilakukan secara baik, maka akan dapat terbentuk wirausaha yang diharapkan oleh pendamping.

\section{Metode Ceramah}

Masyarakat diberikan wawasan mengenai peluang wirausaha, sehingga dari penyampaian yang diberikan dapat memotivasi masyarakat untuk menerapkannya dalam kehidupan sehari-hari. Sebab selama ini masyarakat cenderung sudah terbiasa dengan mata pencaharian sebelumnya yaitu bertani dan berladang, sehingga denganmetode ini, ingin mengubah pola pikir masyarakat bahwa dengan berwirausaha juga merupakan suatu pekerjaan yang dapat menghasilkan pendapatan.

3. Menyusun rencana kegiatan dan pembinaan.

Pendamping bersama perangkat desa yang berfungsi sebagai mitra nantinya sebagai pembekal dalam menggali potensi masyarakat untuk menanamkan pada pikiran masyarakat, mengenai peluang wirausaha, sehingga dalam hal ini pengabdi dapat menyusun rencana kegiatan yang akan melibatkan masyarakat sekitar untuk dibina menjadi wirausahawan.

\section{Metode tutorial}

Dalam kegiatan ini, masyarakat diberikan materi dan tutorial tentang cara melakukan dan membuat produk dari bahan sederhana atau pun produk yang murah tapi mempunyai nilai jual dan mengajarkan cara berkreasi dalam menghasilkan produk tersebut. Sehingga dari tutorial yang dibagikan, maka masyarakat khususnya ibu-ibu yang sebelumnya belum terpikir untuk membuat kue dari bahan alam desa, menjadi lebih terbuka dan dari hasil tutorial tersebut, masyarakat menjadi lebih paham, ketika ada produk yang berbahan baku sederhana tetapi dapat menghasilkan produk yang bernilai jual, sehingga dapat menghasilkan pendapatan bagi masyarakat.

\section{HASIL DAN PEMBAHASAN}

Untuk dapat memberikan pendampingan , maka pada pengabdian kepada masyarakat ini memerlukan beberapa proses, sehingga pengabdi dapat menyampaikan kegiatan sosialisasi kepada masyarakat. Proses tersebut seperti:

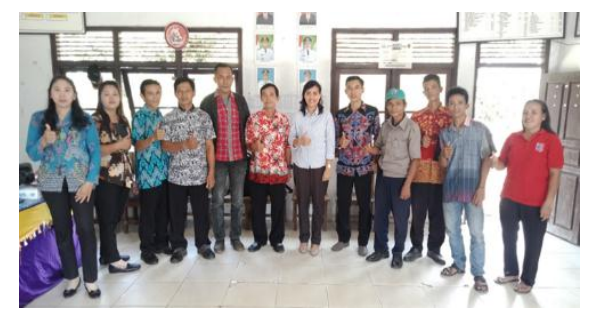

Gambar 1. Koordinasi bersama perangkat desa

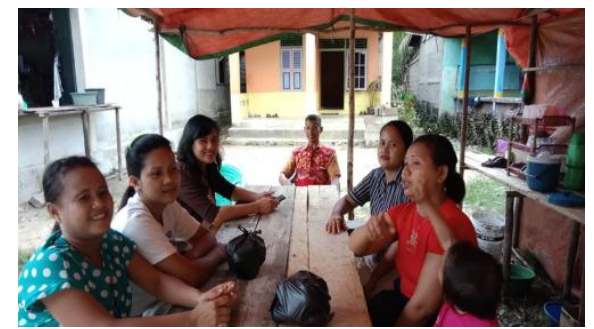

Gambar 2. Diskusi bersama masyarakat dusun 


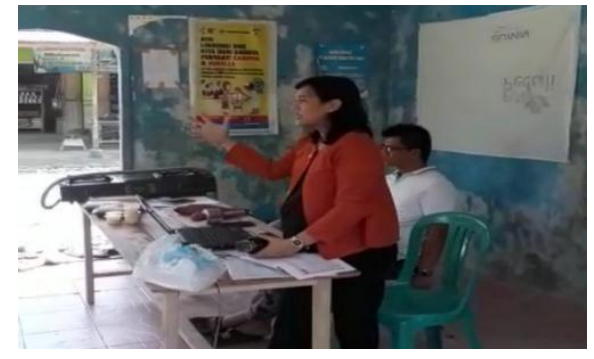

Gambar 3. Proses sosialisasi pendampingan kepada masyarakat

Kegiatan Pengabdian Pada Masyarakat yang berjudul Pendampingan Peluang Kewirausahaan Pada Masyarakat Dusun Sekinyak Dalam Bidang Pariwisata yang dilaksanakan di daerah tersebut menghasilkan:

1. Pada saat pendamping menyampaikan tutorial tentang kegiatan yang dapat menghasilkan produk berdaya jual yang diikuti oleh masyarakat dusun setempat, sehingga masyarakat dapat lebih memahami proses jalannya produksi suatu produk secara langsung. Sehingga dari kegiatan tersebut, dapat membuka pikiran masyarakat untuk meghasilkan produk dari bahan alam di desa.

2. Penanaman pola pikir dari pendampingan mengenai kewirausahaan yang sebelumnya masyarakat hanya mengerti tentang pertanian saja, tetapi setelah dilakukan pembinaan masyarakat menjadi lebih paham, mengenai arti pentingnya kewirausahaan, sehingga masyarakat dapat membaca adanya peluang berwirausaha di daerah tersebut.

Dengan adanya kegiatan pendampingan yang dilakukan oleh pengabdi ini, diharapkan ke depannya, pengetahuan yang diperoleh dari pengabdi dapat diimplementasikan oleh masyarakat, sehingga manfaatnya juga kelak akan dirasakan oleh masyarakat, seperti dapat menambah pendapatan keluarga dari usaha baru seperti memproduksi kuliner khas daerah maupun memproduksi kerajinan tangan.

Manfaat lainnya, dari hasil pendampingan tersebut terdapat waktu luang yang akan digunakan oleh masyarakat sekitar sehingga mengurangi kegiatan yang tidak bermanfaat. Di samping itu terdapat manfaat adanya kebersihan lingkungan, keamanan dusun, timbulnya kreatifitas dalam bisnis dan pelestarian alam dapat terjaga dengan baik.

\section{SIMPULAN}

Berdasarkan hasil analisa dari kegiatan pengabdian masyarakat ini, maka dapat diambil kesimpulan bahwa dengan adanya kegiatan pendampingan ini membentuk pola pikir masyarakat untuk dapat berusaha menjadi seorang wirausaha. Selain itu potensi objek wisata di dusun Sekinyak memberikan peluang usaha bagi masyarakat di dusun tersebut. Dengan adanya peluang usaha tersebut dapat memberikan usaha dan pendapatan sampingan bagi masyarakat khususnya dan pendapatan daerah pada umumnya.

\section{Saran}

Pendampingan yang rutin akan berdampak pada mulai terbentuknya pola pikir masyarakat, yang sebelumnya hanya berpola pada mata pencaharian sebagai petani, tetapi dengan adanya sosialisasi dengan adanya peluang usaha karena terdapat objek wisata, maka perlahan masyarakat akan mulai berwirausaha untuk mendapat pendapatan 
yang lebih baik. Diharapkan adanya kerjasama semua pihak dalam mengembangkan potensi wisata baik dari masyarakat, pemerintah daerah, pihak akademisi serta pihak swasta dalam memberikan kontribusi yang cukup berpengaruh bagi perkembangan daerah wisata tersebut. Dengan adanya peluang usaha di daerah pariwisata, jika diterapkan dan dikoordinasi dengan baik oleh semua pihak, maka daerah wisata tersebut akan banyak dikunjungi dan semakin dikenal oleh pihak luar. Pengabdi juga mengucapkan terimakasih institusi STIM Shanti Bhuana serta PRPM yang telah memberi dukungan terhadap kegiatan pengabdian ini, serta pengabdi juga berterimakasih kepada Camat Lumar, Kepala Desa Belimbing serta Kepala Dusun Sekinyak dan seluruh peserta kegiatan sosialisasi maupun pendampingan ini, serta semua pihak yang telah terlibat.

\section{DAFTAR RUJUKAN}

Adiyoso, W. (2009). Menggugat Perencanaan Partisipatif dalam Pemberdayaan Masyarakat. Jakarta: ITS Press

Arikunto, S. 2006. Prosedur Penelitian Suatu Pendekatan Praktik. Jakarta: Rineka Cipta.

Moleong, Lexy J. (2001). Metodologi Penelitian Kualitatif.Bandung: Remaja Rosdakarya

Puspaningtyas, M., Bahtiar, M. D., Putri, D. M., Ekonomi, F., Malang, U. N., \& Karangpatihan, D. (2018). Peningkatan kemampuan berwirausaha masyarakat desa wisata gunung beruk. Jurnal KARINOV, 1(3), 1-7.
Sugiyono. 2005. Metode Penelitian Bisnis. Alfabeta. Bandung.

Wearing, S.L. and Donald, Mc. 2001. "The Development of Community Based Tourism: Re-Thinking The Relationsgip between Tour Operators and Development Agents as intermediaries in rural and isolated area Communities." Journal of Sustainable Tourism.

Zuriah, Nurul. 2009. Metodologi Penelitian Sosial dan Pendidikan. Jakarta: Bumi Aksara 